\title{
Identification of backward regions of Kashmir Valley (India)- A Spatio -temporal approach
}

\author{
Shahnaz Mohiuddin \\ Department of Geography Jamia Millia Islamia, New Delhi, Pin code 11025.
}

Accepted 18 October, 2013

\begin{abstract}
The issue of regional development has been widely discussed in relation to a developed area and development at an aggregate level rather than focusing attention exclusively on the backward regions. Scholars have tried to define the term 'backward region' with reference to the typical problems encountered by such regions, their potential for development, efficacy of regional plans and factor endowments. Hence, it is necessary to look at the backward regions of India with special emphasis on Kashmir Valley which is one of the three regions of Jammu and Kashmir States. Examination of the stated problem in this investigation requires a huge data from both primary and secondary sources which is followed by a set of indicators. A number of statistical methods like standardization and construction of composite index through factor analysis were employed in the present study. This is followed by the classification of tehsils (unit of analysis or sub-district) on the basis of their development with an aim to emphasize the backward areas and the dynamics of backwardness. Most of the units (study units) were found to be in backward category either in one or the other sector of development. Hence, it is extremly important to emphasize the integrated sectoral development rather than individual sectors.
\end{abstract}

Key words: Regional development, backward region, India, Kashmir Valley, Levels of development, factor analysis, sectoral development.

\section{INTRODUCTION}

The term, development or backwardness, is highly subjective. There are numerous definitions of these two terms. Development or backwardness may relate to any field, social, political, physical, psychological, natural, technological and moral. In economics, these two terms are commonly used with reference to availability of per capita real income, employment opportunities, infrastructure facilities, amenities and services. These two terms can also be interpreted as an increase or decrease in the material well being of the population inhabiting a particular area. This material well being is reflected in the present study by either an increase or decrease in the levels of development in the major sectors of the economy as shown by the value of indicators selected.
Unequal development gives rise to various problems, such as unsustainable use of natural resources, increase in poverty and a major obstacle to national integration. There are a number of scientists in social and economic studies who analysed the adverse impact of persisting inequalities. Harvey (1964) and Williamson (1965) observed that continuous regional inequalities in the levels of development are dangerous for social cohesion. According to him, national employment could be increased if regional unemployment disparities are reduced. There is a huge possibility of growth and development if disparities are reduced. Myrdal (1957) and Dholakia (1985) observed that regional disparities are more common in underdeveloped nations than the developed 
nations. Inequality leads to polarization among societies in general and regions in particular.

The virtual disparity in terms of social, economic, political and most importantly infrastructural status has been growing between rural and urban India throughout the last three decades. Rural areas across the country are paralyzed with a wide spectrum of severe problems like lack of access to drinking water and other civic amenities, outdated techniques of traditional agrarian systems, increasing rate of soil and natural resource degradation, poor communication status, low level of per capita income, gender inequality, less participation in community decision making and so on (GOI, 1981).

All the adverse impact discussed so far demands immediate measures to minimize regional disparities. Backward regions in such cases need proper attention and assistance so that their potential is properly harnessed enabling them to attain higher levels of development. This needs to have proper planning and strategy for the overall development of such regions. In order to adopt a policy to minimize the impact of regional disparities we have to face a fundamental problem related to the adoption of a clear concept of region and its backwardness. This in turn would help us to have a clear understanding of the problems of such regions and their future prospectus.

There have been continuous efforts to define the term 'backward region' but they are quite indistinct, and have failed to give a clear picture of what exactly constitutes a region, with reference to the typical problems faced by such regions. It is quite challenging for a researcher to study backwardness of a region without a common definition. This problem is evident in the report presented by the National Committee on the Development of Backward Areas (NCDBA). In its view, "a clear cut concept of backwardness seems to be missing". A major study to classify the regions according to their problems was produced by the Organisation of Economic Cooperation and development (OECD). Based on its study of 15 industrialised countries, it classified regions into four types. They are developed, under developed, reconversion and congestion regions. Out of these four types, the first is highly relevant in the present study. The National Committee on the Development of backward Areas has listed six types of backward regions facing various adverse physical problems. They include chronically drought prone areas, desert areas, chronically flood affected areas and coastal areas affected by salinity.

After proper understanding of the backward regions, it is highly imperative to adopt an exact identification of such regions. Further it is important that one should have a clear conception of the principles which guide us in the selection of these regions. In a country like India, identification of backward regions is extremely important to reduce regional disparities. This type of identification helps in the transfer of resources from centre. Also the states in the absence of such identifications may set their own goals for additional assistance and investment. There are two ways which have been suggested by the National Commission on the Development of Backward Areas (NCDBA) to operationalise the concept of backwardness. The first is to rely on some overall index of regions and treat those regions which are below some cutoff point as backward. The second is to identify problem regions under different categories by identifying the obstacles on development that can be mitigated by special means. This in turn will help us to understand the problems and prospectus of such regions (GOI, 1969; 1999).

Though the entire state of Jammu and Kashmir is backward, there exists within the state areas which have not been uniformly affected by the process of social and economic development, and hence these areas remain much more backward than the rest of the state (Hussain 1998). Kashmir Valley is one of the provinces which are most backward in the levels of development. Against this backdrop, there is a need to identify the regions or areas which are backward. Hence, it is highly needed to look into the dynamics of the regional backwardness over space and time. Also, it is imperative to understand the contribution of the present study with its major emphasis on the reduction of inequalities among regions and emphasis on intersectoral development. The present study is an attempt in this direction and has the following aims and objectives.

\section{Aim}

To identify backward regions of Kashmir Valley and explain their nature of backwardness

\section{Objectives}

1. To identify the relatively backward areas in the Kashmir Valley.

2. To classify the areas (tehsils) on the basis of differential levels of development and to mark interregional variations.

3. To analyze the factors responsible for the backwardness of these areas.

4. To suggest appropriate strategies to reduce their backwardness.

A brief geographic profile of the Kashmir Valley covering all the physiographic divisions is presented as follows. An in-depth analysis of the productive sectors covering agriculture and industry, social sector with education and health, economic infrastructure covering transport and communication was done at inter-tehsil level. Problems and prospects of backward districts have been given special focus. The final paragraph contains the major 
$74^{\circ} 00^{\prime}$

$75^{\circ} 30^{\circ}$

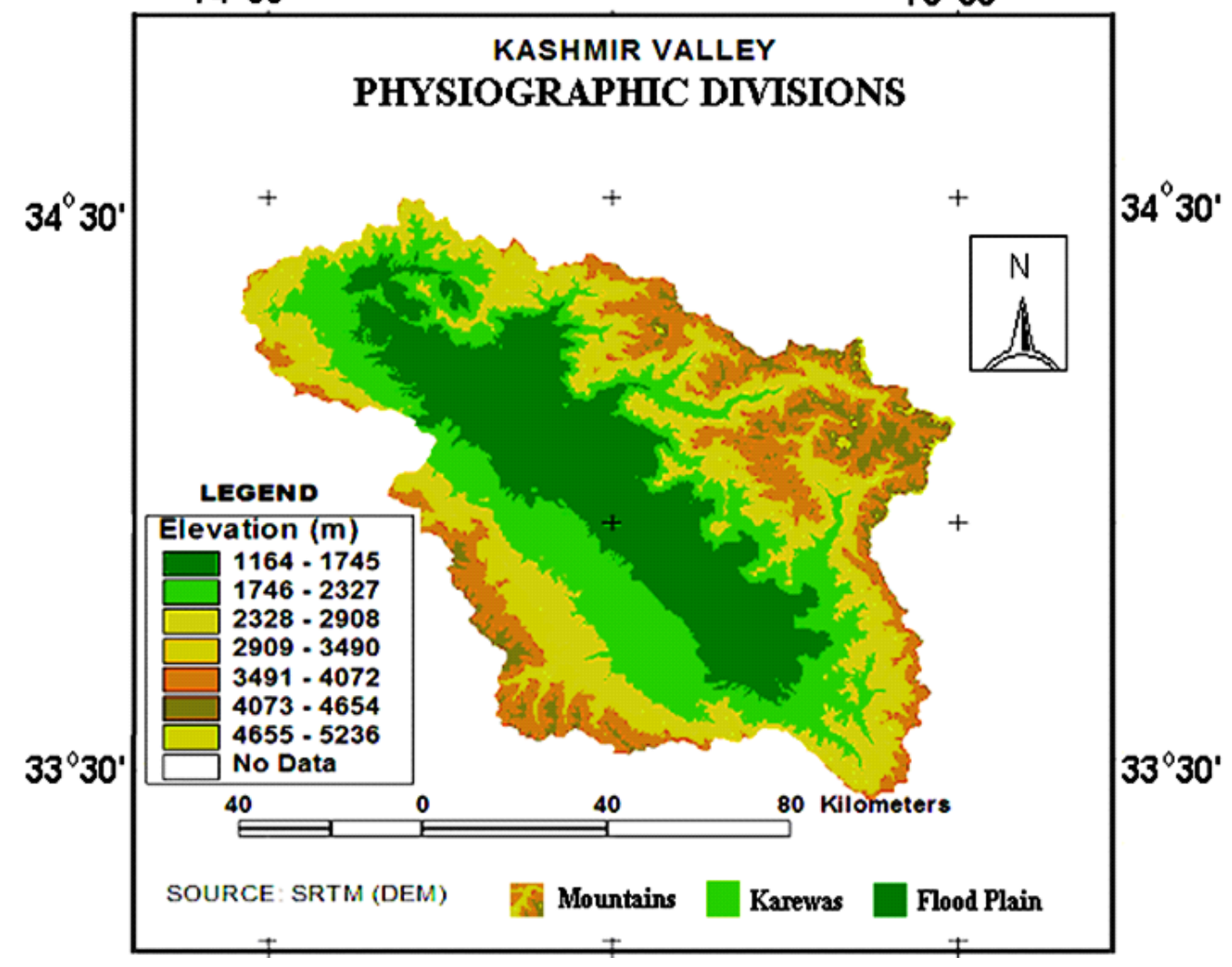

Figure 1. Physiographic divisions of Kashmir Valley.

findings, policy suggestions and conclusions. It presents a detailed analysis of dimensions of development and typology of backwardness of tehsils with different policy options, strategies and approaches to reduce regional disparities in the Kashmir Valley.

\section{The study area}

Kashmir valley has a unique geographical setting. It is an oval shaped synclinal basin about 150 kilometers long and 42 kilometers wide, with a floor situated in the Jhelum flood plain; 1,585 meters (5,200 feet) above the sea level. This fertile plain of Jhelum is surrounded on all sides by high mountains with heights ranging from 3,900 to 5,400 meters above the sea level. Its south and southwest border is formed by the Pir Panjal range whereas the great Himalayas and north Kashmir ranges make its north and north-eastern boundary, thus cutting it off from the frost bitten desert plateau of Ladakh. The slopes of these mountains are drained by a number of tributaries which later meet the main stream of Jhelum.

On the basis of topographic features, altitude, slope, climate, and pedalogical conditions, the region is divisible into the following physiographic divisions as shown in
Figure 1.

1. The Valley Floor

2. The Karewas

3. The Rimlands

The flat bottom of the Valley is of the deposits of fluiolacustrine origin overlain by a depository of rock material of great thickness from the surrounding mountains. The older deposits of upper Pleistocene, called Karewas are flat surfaces along the flanks of mountains. The Jehlum flood-plain occupies more than half of the Valley bottom.

The recent alluvium of geologically sub- recent times is found in the flood plains of Jehlum. It extends over three to thirty five $\mathrm{km}$ along the course of the Jehlum and covers a large area. This region being fertile provides a base for intensive agriculture and is diversely populated for thatt matter (Raina, 1971: 45-51; Raza et al., 1978: 29; Hussain, 1998: 29).

These diversities in physography, climate, soils and vegetation are quite disadvantageous for harmonious development of all the regions of the state. They are natural constraints and they will have to be accepted as such. But what is more worrying for the planners and policy makers is the problem of glaring disparities across 
Table 1. Factor matrix for aggregate development.

\begin{tabular}{lcc}
\hline Indicator & Factor 1 & Factor 2 \\
\hline Agriculture development index & 0.180 & 0.935 \\
Industrial development index & 0.731 & 0.370 \\
Education development index & 0.941 & -0.122 \\
Health development index & 0.842 & -0.288 \\
Road development index & 0.862 & 0.002 \\
Communication development index & 0.918 & -0.090 \\
\hline
\end{tabular}

Source: Computed Values of Composite Indices of (Agriculture, Industries, Education, Health, Roads and Communication).

Different regions. This is because Kashmir Valley's economy when looked at spatially has a considerable diversification. The spread of agricultural, industrial, banking, commerce and public sector functions such as education, medical care or irrigation is quite complex. Alarming rise in the rate of population, unemployment, low literacy level, lop sided concentration of infrastructure and modern civic amenities in few urban centres poses grave problems for the overall development of the valley (Khan 2006). How do these factors influence the regional development, what is the magnitude of these inequalities, how region specific magnitude of inequalities has changed over the period of time? These research questions have rarely being discussed so far. Keeping in view this research gap, the present study attempts to answer these questions.

In order to study the regional inequalities and their outcome in the form of backward regions over time and space with special reference to Kashmir Valley, tehsil has been taken as a unit of study (Prakash and Rajan 1979).

\section{MATERIALS AND METHODS}

Examination of the stated problem in this investigation requires a huge data from both primary and secondary sources. On an average there are 1255 households in each tehsil (unit of analysis). The primary data were obtained by adopting quota sampling technique and 100 households were taken from each tehsil. This was done by dividing the tehsil on the basis of economic criteria like very high, high, low, very low income households. Hence, twenty five households were taken from each economic class. The secondary data were obtained from different government offices and agencies. Information about stratigraphy and geology of the region was obtained from Geological Survey of India (G. S.I), Srinagar. Information about climate (temperature, rainfall and humidity) was obtained from the Metrological Department, Srinagar. Agriculture and irrigation statistics was obtained from the statistical branch of the Financial Commissioner's office, Srinagar. Data regarding industries and employment were obtained from the Directorate of Industries and Commerce, J\&K and Directorate of Employment Exchange. Data regarding different population attributes were obtained from Directorate of Census Operations, Jammu and Kashmir. Apart from this, the information was collected from Digest of Statistics, published by the Government of Jammu and Kashmir. This is followed by a set of indicators to be used in the present study (see annexures). These indicators were assigned statistical weights derived through factor analysis method. The indicators are then standardised and on the basis of factor matrix an index of sectoral development has been prepared. All the tehsils were classified on the basis of average for each sector, into highly developed, developed, backward and highly backward. This methodology, which is considered as highly objective and unbiased, identifies differentially developed tehsils with the following eight indicators.

1. Agriculture development index derived from nine indicators

2. Industrial development index with eight indicators

3. Education development index using fourteen indicators

4. Health development index using five indicators

5. Transport development index using four indicators

6. Communication development index using four indicators

7. Power development index using nine indicators and

8. Banking development index using four indicators

An important finding that emerges from the Table 1 is that development in Kashmir Valley was not uni-dimensional. This would be clear when we examine the factor matrix given in the table.

The factor matrix brings out very clearly the bi-dimensional development in the Kashmir Valley. While the first factor explains the overall levels of development highlighting the contribution from non-agricultural sectors, the second factor represents development mainly in the agricultural sector. If we look at the factor loadings on the first factor, it is clear that the indicators of agriculture and education are very high. On the second factor, infrastructure has the highest loading, followed by industries. Thus, it truly reflects the bi- dimensional development that has taken place in the valley.

The first factor also has positive and significant correlation with all the indicators. Therefore, the first factor relies upon realistic analysis about the levels of development of tehsils across the Valley. Tehsil-wise factor scores or index of development were derived, which gives a comparative picture of levels of development of all the tehsils of the Kashmir Valley over a period of twenty years (from 2001 to 2011) (Table 2).

\section{RESULTS AND DISCUSSION}

The Srinagar tehsil occupies the prime place in both the time-points with exceptionally high index values. Sopore tehsil is placed at distinct second. Uri and Karnah are figured in the lowest order in both time-points. Three tehsils namely, Baramulla, Ganderbal and Ananthnag are figured in the highly developed category in 2001. The negative sign of this trend is that two tehsils, Kulgam and Bijbehara got slid down from vey developed to developed category. The sole reason for this change is the slow pace of development by both these tehsils during the process of development.

However, along with this positive development, the study notices the problem of increasing inter- tehsil disparities. To probe the factors that have contributed to the widening of disparities, we can classify all the tehsils into four categories. As pointed out earlier, Srinagar tehsil (rural and urban) combined emerges as the highly developed, having scored exceptionally high index values in both the time-points. Srinagar tehsil is followed by Sopore, Baramulla, Anantnag and Ganderbal in the same category. 
Table 2. Index of aggregate levels of development.

\begin{tabular}{lcccc}
\hline \multirow{2}{*}{ Tehsil } & \multicolumn{2}{c}{ 2001 } & \multicolumn{2}{c}{ 2011 } \\
\cline { 2 - 5 } & Index & Rank & Index & Rank \\
\hline Anantnag & 0.42 & 6 & 0.71 & 4 \\
Bijbehara & 0.46 & 5 & 0.52 & 6 \\
Duru & 0.01 & 9 & 0.09 & 9 \\
Kulgam & 0.71 & 3 & 0.34 & 7 \\
Pahalgam & -0.87 & 19 & -0.82 & 19 \\
Budgam & 0.33 & 8 & 0.27 & 8 \\
Beerwah & -0.40 & 13 & -0.38 & 14 \\
Chadura & -0.73 & 18 & -0.74 & 18 \\
Bandipora & -0.52 & 16 & -0.44 & 15 \\
Baramulla & 0.71 & 4 & 0.87 & 3 \\
Gulmarg & -1.03 & 21 & -0.97 & 20 \\
Sonawari & -0.33 & 12 & -0.23 & 13 \\
Sopore & 1.02 & 2 & 1.02 & 2 \\
Uri & -0.89 & 20 & -1.20 & 21 \\
Handwara & -0.44 & 14 & -0.63 & 16 \\
Karnah & -1.07 & 22 & -1.29 & 22 \\
Kupwara & -0.49 & 15 & -0.69 & 17 \\
Pulwama & -0.10 & 10 & 0.06 & 10 \\
Shopian & -0.14 & 11 & -0.17 & 11 \\
Tral & -0.58 & 17 & -0.22 & 12 \\
Ganderbal & 0.38 & 7 & 0.53 & 5 \\
Srinagar & 3.57 & 1 & 3.37 & 1 \\
\hline
\end{tabular}

Six tehsils like Bijbehara, Kulgam, Budgam, Duru, Pulwama and Shopian are figured in the developed category in both time in 2001. Bandipora, Beerwah, Handwara, Sonawari, Kupwara and Tral are figured in the backward category. While, Chadura, Gulmarg, Karnah, Pahalgam and Uri are figured in the highly backward category in both time points.

It is interesting to note that the trend in development remained almost the same from 2001 to 2011 except some tehsils like Bijbehara and Kulgam which could not attain the pace of development and got slid down from highly developed to developed category. This shows that the tehsils which were highly developed in 2001 could not retain their position in the same category in 2011. On the other hand, it is very interesting to know that the tehsils which are figured in the backward and highly backward category in 1981retained the same position in 2011.

Thus if we compare the two time-points, we can clearly see the distance between highly backward and highly developed regions has remained in the same category in both time points. If we consider the index values of the first and last ranked tehsils during 2011, (Srinagar with (3.37) and Karnah with (-1.29)) the wide gap is quite evident. Similarly, a huge gap appears if we compare the other tehsils in the developed and backward category.

A region wise glance of tehsils in the two time points with their index values support the long standing view that the degree of overall economic backwardness is greater in the hilly and Kandi areas. Not even a single tehsil of these regions is figured in the developed category in both the time-points. The position in the Karewa belt is better when compared to hilly and kandi areas of the valley. This region has an enormous potential to grow and location close to the Jhelum Floor belt is providing boost for its growth and development.

The predominant position of Sopre and Srinagar tehsils is evident from all the angles of development. In fact, the very high rate of development of both these tehsil is one of the principle factors, which has pushed up the index of their development. Therefore, it is quite evident that there is uneven socio-economic development across all the tehsils of the Kashmir Valley. Both developed and backward tehsils are scattered across different regions.

\section{Dimensions of development}

According to Rao (1984), the term dimension implies four possibilities. First of all, all the sectors in a district or tehsil may be totally developed or backward. Other possibilities could be that a district or a region may experience uni-sectoral, bi-sectoral and multi- sectoral development or backwardness.

One should have a clear perception of all the four possibilities to evolve different strategies of development and formulate sectoral plans. In addition, once the dimensions are known we can proceed further to have a clear view of typology of backwardness. This helps us to understand the type of development in a tehsil, i.e. whether a tehsil is agriculturally developed or backward or industrially developed or backward or there is a combination of all these sectoral developments or backwardness. If we are definite with the typology of backwardness, the task of fixing priorities for the development of lagging sectors becomes easier.

Table 3 gives some insights into the disturbing issues raised in the previous paragraphs such as problems of increasing disparities and the widening gap across the tehsils. The first negative feature that emerges from the table is that while Sopore is almost having a distinction of all developed sectors. The rest of the tehsils could not maintain this status. Srinagar, Baramulla, Anantnag and Ganderbal achieved multi-dimensional development but are lacking in one or the other sector. Most of the tehsils maintained their status and could not excel to show their development. Most of the tehsils witnessed a decline in their dimensions of development. Only Srinagar, Sopore and Anantnag could be placed in the higher order with multi-sectoral development. This clearly brings out the direct and positive relationship between the levels of development and dimensions of development. This implies that, with increase in the levels of development, there would be an increase in the dimensions of development from uni-sectoral to bi-sectoral and then to multisectoral development. It highlights interdependency 
Table 3. Classification of tehsils on the levels of aggregate development.

\begin{tabular}{|c|c|c|c|c|}
\hline Year & Highly developed & Developed & Backward & Highly backward \\
\hline 2001 & $\begin{array}{l}\text { Srinagar, Sopore, } \\
\text { Kulgam, Bijbehara, } \\
\text { Baramulla }\end{array}$ & $\begin{array}{l}\text { Anantnag, } \\
\text { Budgam, Duru, } \\
\text { Ganderbal, } \\
\text { Pulwama, Shopian }\end{array}$ & $\begin{array}{l}\text { Bandipora, } \\
\text { Beerwah, } \\
\text { Handwara, } \\
\text { Kupwara, Sonawari, } \\
\text { Tral }\end{array}$ & $\begin{array}{l}\text { Chadura, Gulmarg, } \\
\text { Karnah, Pahalgam, Uri }\end{array}$ \\
\hline 2011 & $\begin{array}{l}\text { Srinagar, Sopore, } \\
\text { Baramulla,Ganderb- } \\
\text { al Anantnag }\end{array}$ & $\begin{array}{l}\text { Budgam, Duru, } \\
\text { Kulgam, Bijbehara, } \\
\text { Pulwama, Shopian }\end{array}$ & $\begin{array}{l}\text { Bandipora, } \\
\text { Beerwah, } \\
\text { Handwara, } \\
\text { Kupwara, Sonawari, } \\
\text { Tral }\end{array}$ & $\begin{array}{l}\text { Chadura, Gulmarg, } \\
\text { Karnah, Pahalgam, Uri }\end{array}$ \\
\hline
\end{tabular}

among different sectors in the regional development process, underlining the crucial significance of adopting integrated regional and sectoral approaches to set up aggregate development of a region.

In practical sense, it implies that developmental strategies should be formulated and implemented in such a way that development in one sector could induce development in other sectors as well. Judging from this angle, it is rather discouraging to see that in spite of sustained increase in index values by most of the tehsils in many sectors, a large number of tehsils have remained backward from the point of dimensions of development. A total of eleven tehsils have multi sectoral backwardness. This is indeed a situation of great concern. It points towards the failure of growth dispersion mechanism from the developed to the backward regions. Hence, proper inter-regional and inter-sectoral developmental measures assume crucial importance. To evolve such measures, clear understanding of typology of backwardness is also very much essential.

\section{Typology of backwardness}

A clear understanding of dimensions of development is helpful to probe into various issues pertaining to the typology of backwardness. Here, the basic assumption is that there is a definite relationship between the levels of development and typology of backwardness. This is reflected in Table 4.

From Table 4, it is clear that the developed tehsils have comparatively very few backward sectors and vice versa. A closer look at the typology of backwardness of tehsils reveals that a total of eleven tehsils were in backward and highly backward category in 2001 and their number declined to ten in 2011.

If we take the social sector, eleven tehsils in the educational and eleven in the health sector were in backward and highly backward category during 1980-81 and their number remained the same in 2000-01. Economic infrastructure base is weak in most of the tehsils in the valley. A total of twelve tehsils in roads and eleven tehsils in communication sector were backward and highly backward during 1980-81. Here also, their number almost remained the same in 2001 . This adversely affected the development prospectus in these tehsils and showed that the tehsils which were already backward and highly backward did not show any progress in their levels of socio-economic development. These three types of backwardness, namely, backwardness in economic sector, social sector and infrastructure seen across various tehsils reveal an important fact that as the levels of development go up, the typology undergoes change. The change is witnessed in the form of progress in the secondary and tertiary sectors.

Therefore, in general the developed tehsils have well developed economic infrastructure base. In the initial stages of development, progress is restricted to a few sectors (Table 5), but in the subsequent stages the number of developed sectors should increase provided there is an appropriate strategy of development. Thus, proper identification of backward tehsils, their dimension of development and a clear understanding of the trends in disparities as analysed so far should form the basis of any developmental strategy to increase the overall growth rate and decrease inter-tehsil disparities. Various policy options and suitable strategies to attain these twin goals have been discussed in the following section.

\section{Suggestions}

The various policies and programmes of the Government of India and Govt. of Jammu and Kashmir for the overall regional development in the state revolve around major schemes. They are Drought Prone Area Programme, Hill Area Development Programme, Command Area Development Programme, National Rural Health Mission, Serva Siksha Abhiyan etc.

All the above mentioned programmes of Government of 
Table 4. Typology of backwardness 2001 and 2011.

\begin{tabular}{|c|c|c|c|c|c|c|c|c|c|c|c|c|}
\hline \multirow{2}{*}{ Tehsils } & \multicolumn{6}{|c|}{2001} & \multicolumn{6}{|c|}{2011} \\
\hline & A & I & ED & $\mathbf{H}$ & $\mathbf{R}$ & C & A & I & ED & $\mathbf{H}$ & $\mathbf{R}$ & C \\
\hline Anantnag & B & $\mathrm{HB}$ & $\mathrm{HD}$ & $H D$ & D & $\mathrm{HD}$ & D & B & $\mathrm{HD}$ & $\mathrm{HD}$ & D & $H D$ \\
\hline Bijbehara & D & $H D$ & D & $\mathrm{HB}$ & $\mathrm{HD}$ & D & $\mathrm{HD}$ & HD & B & B & $\mathrm{HD}$ & D \\
\hline Duru & HD & B & D & D & D & D & $\mathrm{HD}$ & D & D & $\mathrm{HB}$ & D & D \\
\hline Kulgam & B & D & D & $H D$ & $\mathrm{HD}$ & $H D$ & D & $\mathrm{HB}$ & D & D & $\mathrm{HD}$ & $\mathrm{HD}$ \\
\hline Pahalgam & D & B & $\mathrm{HB}$ & B & B & $\mathrm{HB}$ & B & D & $\mathrm{HB}$ & $\mathrm{HB}$ & B & $\mathrm{HB}$ \\
\hline Budgam & D & $\mathrm{HD}$ & B & D & D & D & D & $\mathrm{HD}$ & B & B & $\mathrm{HD}$ & $\mathrm{D}$ \\
\hline Beerwah & $\mathrm{D}$ & $\mathrm{D}$ & $\mathrm{HB}$ & B & $\mathrm{B}$ & $\mathrm{B}$ & $\mathrm{B}$ & $B$ & $\mathrm{HB}$ & B & $\mathrm{D}$ & $B$ \\
\hline Chadura & $\mathrm{HB}$ & $\mathrm{B}$ & $\mathrm{B}$ & B & $\mathrm{HB}$ & $\mathrm{HB}$ & $\mathrm{HB}$ & $D$ & $B$ & $B$ & $\mathrm{HB}$ & $\mathrm{HB}$ \\
\hline Bandipora & $\mathrm{HB}$ & $\mathrm{HB}$ & $\mathrm{D}$ & $\mathrm{D}$ & $B$ & $B$ & $B$ & $\mathrm{HB}$ & $\mathrm{D}$ & $\mathrm{HD}$ & $\mathrm{HB}$ & $B$ \\
\hline Baramulla & $\mathrm{D}$ & $\mathrm{D}$ & $\mathrm{HD}$ & $\mathrm{HD}$ & $\mathrm{D}$ & $\mathrm{HD}$ & $\mathrm{B}$ & $\mathrm{HD}$ & $\mathrm{HD}$ & $\mathrm{D}$ & $\mathrm{HD}$ & $\mathrm{HD}$ \\
\hline Gulmarg & $\mathrm{HB}$ & $\mathrm{HB}$ & $\mathrm{HB}$ & $\mathrm{HB}$ & $\mathrm{HB}$ & $B$ & $\mathrm{HB}$ & $\mathrm{HB}$ & B & $B$ & $\mathrm{HB}$ & B \\
\hline Sonawari & HD & B & $\mathrm{HB}$ & $\mathrm{D}$ & $\mathrm{HD}$ & $\mathrm{HB}$ & $\mathrm{D}$ & $\mathrm{D}$ & $\mathrm{HB}$ & $H D$ & $\mathrm{D}$ & $\mathrm{HB}$ \\
\hline Sopore & $H D$ & D & $\mathrm{HD}$ & $H D$ & $\mathrm{HD}$ & $H D$ & $\mathrm{HD}$ & D & $\mathrm{HD}$ & $\mathrm{HD}$ & $\mathrm{HD}$ & $H D$ \\
\hline Uri & B & D & B & $\mathrm{HB}$ & $\mathrm{HB}$ & $\mathrm{HB}$ & $H D$ & $\mathrm{HB}$ & $\mathrm{HB}$ & D & $\mathrm{HB}$ & $\mathrm{HB}$ \\
\hline Handwara & $\mathrm{B}$ & $D$ & $B$ & $\mathrm{HB}$ & $B$ & $B$ & $B$ & $B$ & $B$ & $\mathrm{HB}$ & $\mathrm{B}$ & $B$ \\
\hline Karnah & $\mathrm{HB}$ & $\mathrm{HB}$ & $\mathrm{HB}$ & $\mathrm{D}$ & $\mathrm{HB}$ & $\mathrm{HB}$ & $\mathrm{HB}$ & $\mathrm{D}$ & $\mathrm{HB}$ & $\mathrm{D}$ & $\mathrm{HB}$ & $\mathrm{HB}$ \\
\hline Kupwara & $\mathrm{HB}$ & B & B & B & D & D & $\mathrm{HB}$ & $\mathrm{HB}$ & B & D & B & $\mathrm{D}$ \\
\hline Pulwama & B & B & $H D$ & B & B & D & B & B & $H D$ & D & B & D \\
\hline Shopian & $\mathrm{HD}$ & $\mathrm{HD}$ & $\mathrm{B}$ & $\mathrm{B}$ & $\mathrm{HB}$ & B & $\mathrm{HD}$ & B & $\mathrm{D}$ & $B$ & B & B \\
\hline Tral & HD & $\mathrm{HB}$ & D & $\mathrm{HB}$ & B & B & D & B & D & $\mathrm{HB}$ & B & B \\
\hline Ganderbal & $\mathrm{D}$ & $\mathrm{HD}$ & $\mathrm{D}$ & $\mathrm{HD}$ & $\mathrm{B}$ & $\mathrm{D}$ & $\mathrm{HD}$ & $\mathrm{HD}$ & $D$ & $\mathrm{HB}$ & $D$ & $\mathrm{D}$ \\
\hline Srinagar & B & $\mathrm{HD}$ & $\mathrm{HD}$ & $\mathrm{HD}$ & $\mathrm{HD}$ & $\mathrm{HD}$ & $\mathrm{HD}$ & $\mathrm{HD}$ & $\mathrm{HD}$ & $\mathrm{HD}$ & $\mathrm{HD}$ & $\mathrm{HD}$ \\
\hline
\end{tabular}

Source: Derived from the computed values of all sectors.

Table 5. Sectoral indices of development.

\begin{tabular}{|c|c|c|c|c|c|c|c|c|c|c|c|c|c|}
\hline 2001 & & & & & & & 2011 & & & & & & \\
\hline Category & A & I & $\mathbf{E}$ & $\mathbf{H}$ & $\mathbf{R}$ & C & Category & A & I & $\mathbf{E}$ & $\mathbf{H}$ & $\mathbf{R}$ & C \\
\hline H. Developed & 5 & 5 & 6 & 6 & 5 & 5 & H. Developed & 7 & 5 & 5 & 5 & 6 & 5 \\
\hline Developed & 6 & 6 & 5 & 5 & 5 & 6 & Developed & 5 & 6 & 6 & 6 & 5 & 6 \\
\hline Backward & 6 & 6 & 6 & 6 & 7 & 6 & Backward & 6 & 6 & 5 & 6 & 6 & 6 \\
\hline H. Backward & 5 & 5 & 5 & 5 & 5 & 5 & H. Backward & 4 & 5 & 6 & 5 & 5 & 5 \\
\hline
\end{tabular}

$\mathrm{A}=$ Agriculture; I= Industrial; $\mathrm{E}=$ Education; $\mathrm{H}=$ Health; $\mathrm{R}=\mathrm{Road}$; $\mathrm{C}=$ Communication.

Jammu and Kashmir are based on regional approach covering more than one tehsils. However, the adoption of regional approach itself is not sufficient. Mere schemewise allocation of financial resources according to the overall objectives of the development of the state is not sufficient. One should look into the sectoral deficiencies across different tehsils and evolve a proper approach to overcome them. In doing so, it is necessary in the first place to combine the regional approach with the sectoral approach for maximum benefit. This combined approach is essential to cater to the specific needs of a region and its potential for future development. This will also lead to the integration of sectoral approach with the spatial process thereby promoting regional development (Anderson and Richard, 2004).

The developed regions and tehsils have benefited substantially from the planned efforts besides having natural advantages. It is in the backward regions that spontaneous developmental activities should gather momentum. These regions require concerted planned efforts to overcome obstacles to growth and also to reduce some of the disadvantageous of adverse natural factors (Friedman 1972).

These regions should become priority regions and there should be an in-depth study of their problems both natural and man made. On the basis of this study, their 
growth potential should be identified and appropriate strategies evolved. Such strategy should aim at the twin goals of crucial significance, namely, increase in the dimensions of development and decrease in the typology of backwardness.

A clear understanding of different dimensions of development is very much needed to evolve proper sectoral planning. In the same way, if we have a clear idea of the typology of backwardness, the task of fixing priorities of the development of lagging sectors becomes easier.

\section{REFERENCES}

Adelman IM (1973). Economic Growth and Social Equity in Developing Countries, Stanford University Press, Stanford, California. Chatfield.

Agarwal A, Hazarika PL (2002). Regional Disparities in Economic Development of Assam- A District Level Study. Indian J. Reg. Sci. 34(2):121-133.

Ahluwalia MS (2002). Economic Performance of States in Post Reform Period, Econmic and Political Weekly. pp.1637-1648.

Anderson K, Richard P (2004). Spatial inequality and Development in Central Asia, In Ravi Kanbur, Anthony, J. Venables and Guangha Wan (eds.), Spatial Disparities in Human Development, Perspectives from Asia, World Institute of Development Economic Research, Res. Paper p.36.

Anita K (2006). Balanced Regional Development in India, Issues and Policies, New Century Publications, New Delhi.

Basavaraj B (2008). Infrastructural development and regional disparity A comparative district level analysis in Karnataka. J. Indian Manage. Strat. 13:41-53.

Bawa R, Sharman M (1983). Sources of Inter-District Variations in Industrial Development in Punjab. Indian J. Reg. Sci. 15:2.

Bhat LS (1972). Regional Planing in India. Statistical Publishing Society, Kolkata.

Chand M, Puri V (1983). Regional Planing in India, Allied Publishers, New Delhi.

Dholakia R (1985). Regional Disparities in Economic Growth in India, Himalaya Publishing House, Bombay.

Myrdal G (1957). Economic Theory and Underdeveloped Regions Gerald Duckworth, London.

Drew K (1971). Jammu and Kashmir Territories: A Geographical Account, Oriental Publishers Delhi.

Friedman JA (1972). Regional Development and Planing, A Reader, Fifth printing, The Massachusetts Institute of Technology, Cambridge. pp.209-223.

Government of India (1969). Working Group on Identification of Backward Areas, Pande Committee. New Delhi.

Government of India (1981). 'Report on development of backward hill areas' Planning commission, Government of India, New Delhi.

Government of India (1981). Identification and Classification of Backward Areas' (From the Draft Report of the Chakravarty Committee on Backward Areas), as presented in Annexure 4.1 of Report on General Issues relating to Backward Areas Development, National Committee on the Development of Backward Areas, New Delhi.

Government of India (1999). Working Group on Fiscal \& Finanncial Incentive for starting Industries in Backward Areas, Wanchoo Committee, New Delhi.

Gupta NS, Prabhakar NC (1988). Socio-Economic Devlopment of Jammu and Kashmir, JK Book House Jammu.
Hammond C (1979), Elements of Human Geography, McGraw Hill, New York.

Harvey A (1964). The Economics Of Regional Policy.The International Library of Critical Writings in Economics series. 544p.

Hemlata R (1984), Identification of Backward Regions and Trends in Regional Disparities in India, Arthavijnana 14(2):67-78.

Hussain M (1998). Geography of Jammu and Kashmir State, Rajesh Publication, New Delhi.

Khan A (2006). Regional Imbalances and Changing Patterns Of Literacy In Jammu and Kashmir state (1961-2001). Indian J. Reg. Sci. 2:97-108.

Kothari S (2001). Analysis of Spatial Disparities in Education and Health Facilities in India. Ann. Rajasthan Geogr. Assoc. pp.XVII-XVIII.

Kumar T (2008). Spatial Analysis of Regional Divergence in India: Income and Economic Structure Perspective. Int. J. Econ. Policy Stud. 3(7):138

Kurian N (2000). Widening Disparities in India- Some Indicators. Econ. Polit. Weekly. 2:548-549.

Lawrence W (1967). The Valley of Kashmir, Kesar Publishers, Srinagar.

Lee C. Dorling D (2011). The Geography of Poverty,Socialist Review, October 2011, http://www.socialistreview.org.uk.

Madhoc B (1963). Kashmir: Centre of New Alignments, Deepak Prakasham Publishers New Delhi.

Pal M (1971). Quantitative techniques in Regional Planning, Indian J. Reg. Sci. p.3.

Pal MN (1963). A Method of Regional Analysis of Economic Development with Reference to South India', J. Reg. Stud. 5:44-58.

Prakash S, Rajan P (1979). Regional Inequalities of Rural Developments, in Madya Pradesh" Indian J. Reg. Sci. 11(1):56-79.

Raina AN (1971). Geography of Jammu and Kahmir, National Book Trust, India, New Delhi.

Raza M, Ahmad A and Mohammad A (1978). The Valley of Kashmir, a Geographical Interpretation (New Delhi:Vikas Publication House).

Williamson G (1965). Regional Inequality and the Process of National Development: A Description of the Pattern. Econ. Dev. Cult. Change. 13:4, Part II. 